\title{
Metallurgical Characterization and Diffusion Studies of Successively Buttered Deposit of Ni-Fe Alloy and Inconel on SA508 Ferritic Steel
}

\author{
Dinesh RATHOD, ${ }^{1) *}$ Sivanandam ARAVINDAN, ${ }^{1)}$ Pavan Kumar SINGH ${ }^{21}$ and Sunil PANDEY ${ }^{1)}$ \\ 1) Department of Mechanical Engineering, Indian Institute of Technology Delhi, New Delhi, 110016 India. \\ 2) Scientist 'G', Bhabha Atomic Research Centre, Mumbai, 400085 India.
}

(Received on October 5, 2013; accepted on May 2, 2014)

\begin{abstract}
The present work aims to investigate the major problem of carbon diffusion in dissimilar metal weld (DMW) between ferritic and austenitic stainless steel used in Nuclear Power Plants. For such DMW joints, Inconel 82 is often deposited on ferritic steel with Gas Tungsten Arc Welding (GTAW) process, but the problems associated with carbon diffusion persist. In the present study, Ni-Fe alloy (ERNiFe-Cl) and Inconel 82 (ERNiCr-3) have been successively deposited with Gas Metal Arc Welding (GMAW) process. The substrates of SA508Gr.3Cl.1 ferritic steel were used for deposition. First buffer layer of $\mathrm{Ni}-\mathrm{Fe}$ alloy was deposited with GTAW in order to have low heat input initially and the subsequent deposition was carried out using GMAW over the buffer layer. The effect of operating temperature of DMW joints on carbon migration from the ferritic steel to buttering zone was studied by carrying out the thermal ageing $450^{\circ} \mathrm{C}$ for $240 \mathrm{~h}$. Diffusivity of carbon at different ageing temperatures was quantified. The effectiveness of buttering deposit was addressed with respect to metallurgical properties and carbon diffusion by carrying out the heat flow analysis, Electron Probe Micro Analysis (EPMA), Optical Emission Spectroscopy (OES), martensite formation analysis at fusion interfaces, micro-hardness variation across the fusion interfaces and the microstructure evolution. Significant amount of martensite was observed to be formed at the fusion interface and the subsequent effect of stress relieving was addressed. Momentous reduction in carbon diffusion and favourable metallurgical properties owing to successive buttering deposit could increase the life of DMW joints with cost effective GMAW over the GTAW process at Nuclear Plants.
\end{abstract}

KEY WORDS: buttering; dissimilar weld; heat flow; EPMA; carbon migration; buffer layer.

\section{Introduction}

In nuclear power plants, ferritic steel pressure vessel nozzles and austenitic stainless steel piping are welded together as DMW joint using Inconel 82/182 filler metal. The ferritic pressure vessel nozzle material is SA508Gr.3Cl.1 steel and austenitic pipe material is SS304LN. Composition compatibility with respect to physical and chemical properties is very important for welding hence SA508 Gr.3Cl.1 is often deposited with Inconel 82 buttering. Certain failures due to leaks and cracks in DMW joints were reported at Palisades wall crack in HAZ, USA (1993), V.C. Summer-USA (2000), Ringhals 3 and 4-Sweden (2000), Biblis A-Germany (2000), Tihang 2-Belgium (2002), Tsuruga 2-Japan (2003), Three mile Island1-USA (2003), and Calvert Cliffs 2-USA (2005). ${ }^{1)}$ Carbon migration leads to formation of carbon depleted soft zone and carbon rich hard zone $\mathrm{e}^{2-13)}$ and this is the major problem which causes the premature failure of DMW joint. As the buttering deposit is adjacent to ferritic steel it will be more affected by carbon migration than the

* Corresponding author: E-mail: dineshvrathod@gmail.com DOI: http://dx.doi.org/10.2355/isijinternational.54.1866 weld metal. Hence selection of suitable filler material for buttering is very important in view of graded composition. ${ }^{14)}$ Ni-base filler metals reduce the diffusivity of carbon, ${ }^{3,6,11,13,15)}$ but it cannot completely eliminate the carbon migration. Higher Chromium content in Inconel 82 buttering adjacent to the SA508 Gr.3Cl.1 could not ascertain the complete hold up of carbon migration. Hence the $\mathrm{Ni}-\mathrm{Fe}$ alloy is used as a buffer layer with subsequent deposit of Inconel 82 with GMAW process owing to faster and clean deposition. As the buttering deposit provides the path for carbon migration from ferritic steel to weld metal, its thickness is also required to be quantified. Dilution of filler metals with base metals during welding causes the diverse variation in the weld metal and hence the number of buttering layers is also required to be examined. Many investigations were conducted to evaluate the DMW joints, $4,5,7,13,16-22)$ but no specific studies on buttering deposit is available. The effect of $\mathrm{Ni}-\mathrm{Fe}$ buffer layer on the buttering deposit in respect of carbon diffusion, variation in metallurgical properties, effective number of buttering layers, thickness and the effect of thermal ageing as well as stress relief post weld heat treatment (PWHT) has been investigated. 


\section{Experimental Details}

SA508Gr.3 Cl.1 ferritic steel in the quenched and tempered condition was used as a substrate in plate form of $150 \mathrm{~mm} \times 50 \mathrm{~mm} \times 15 \mathrm{~mm}$ size. Ni-Fe alloy $($ ERNiFe-CI) filler metal of $2.4 \mathrm{~mm}$ diameter was used to deposit first buffer layer using GTAW and subsequent layer deposition was done using Inconel 82 (ERNiCr-3) of $1.1 \mathrm{~mm}$ diameter by GMAW process. The plates of SA508Gr.3Cl.1 with first buffer layer of $\mathrm{Ni}-\mathrm{Fe}$ alloy have been used. Deposition of buffer layer was carried out using $3 \mathrm{~mm}$ diameter tungsten electrode with straight polarity and argon gas shielding was provided at $9 \mathrm{lit} / \mathrm{min}$. These plates were used to deposit two, three and four layers of Inconel 82 sequentially on each plate. Ni-Fe alloy was used for buffer layer due to its chemical composition and mechanical properties and the GMAW process is selected due to its faster production and cost effectiveness. Subsequent buttering layers were deposited with reverse polarity at $4.57 \mathrm{~m} / \mathrm{min}$ wire feed and argon shielding of $12 \mathrm{lit} / \mathrm{min}$. The $\mathrm{Ni}-\mathrm{Fe}$ alloy buffer layer can lead to graded transition joint in which the composition and concomitant properties can be gradually varied. ${ }^{14)}$ Process parameters for deposition are presented in Table 1.

While depositing the second buttering layer, the heat flow in the depth direction was measured using a K-type thermocouple. The silver brazing was applied to fix the thermocouple on one side of the substrate at $9.2 \mathrm{~mm}$ distance from the top surface. The temperature variation with time was record- ed during the process of buttering.

The chemical composition of each buttered layer of the plates was measured using optical emission spectrometer (OES) and the results were confirmed using EPMA. The schematic of deposited buttered layers and the macrograph of deposited layers are shown in Figs. 1(A) and 1(B) respectively. The deposited four plates were equally cut in three sections for thermal ageing. One section was in as buttered condition while the other two were thermally aged for $330^{\circ} \mathrm{C}$ and $450^{\circ} \mathrm{C}$ for $240 \mathrm{~h}$. The effect of operating temperature on carbon migration was studied by carrying out thermal ageing at operating temperature $\left(310^{\circ}-330^{\circ} \mathrm{C}\right)$ and $450^{\circ} \mathrm{C}$, in order to accelerate the carbon migration. Thermal ageing was conducted for 240 hours as the time required for the transformation of phases to occur at these temperature will be longer. ${ }^{23)}$ The precipitation of $\mathrm{M}_{7} \mathrm{C}_{3}$ carbide starts from $427^{\circ} \mathrm{C}^{24)}$ and the precipitation of secondary phases at $650^{\circ} \mathrm{C}$ takes a very short time span, ${ }^{25,26)}$ and it is known that the decrease in temperature increases precipitation time. The temperatures $\left(330^{\circ} \mathrm{C}\right.$ and $\left.450^{\circ} \mathrm{C}\right)$ were chosen in such a way that the kinetics would be similar to that of the operating temperatures. The buttering associated with DMW joints is often provided with stress relief PWHT at $610^{\circ} \mathrm{C}$ for 90 minutes. One section of the buttered plate was heat treated as per the specified PWHT in order to address the effect of PWHT on hardness properties of the weldment. The samples from each buttered and thermally aged sections were used for EPMA, OES, microstructure evolution, micro-

Table 1. Process Parameters for buttering operation.

\begin{tabular}{|c|c|c|c|c|c|c|c|c|c|}
\hline Deposit & Filler metal & Process & Layer & $\begin{array}{l}\text { No. of } \\
\text { Pass }\end{array}$ & $\begin{array}{l}\text { Current } \\
\text { (amps) }\end{array}$ & $\begin{array}{l}\text { Voltage } \\
\text { (V) }\end{array}$ & $\begin{array}{l}\text { Layer thickness } \\
\qquad(\mathrm{mm})\end{array}$ & $\begin{array}{l}\text { Welding Speed } \\
(\mathrm{mm} / \mathrm{sec})\end{array}$ & $\begin{array}{l}\text { Heat Input } \\
(\mathrm{KJ} / \mathrm{mm})\end{array}$ \\
\hline Single Layer & $\mathrm{Ni}-\mathrm{Fe}$ alloy & GTAW & 1 & 4 & 100 & $9-11$ & 1.60 & 0.54 & 1.85 \\
\hline \multirow{2}{*}{ Two Layer } & $\mathrm{Ni}-\mathrm{Fe}$ alloy & GTAW & 1 & 4 & 100 & $9-11$ & 1.60 & 0.44 & 2.27 \\
\hline & Inconel 82 & GMAW & 2 & 4 & $122-126$ & 23 & 2.03 & 2.58 & 1.11 \\
\hline \multirow{3}{*}{ Three Layer } & $\mathrm{Ni}-\mathrm{Fe}$ alloy & GTAW & 1 & 4 & 100 & $9-11$ & 1.10 & 0.48 & 2.08 \\
\hline & Inconel 82 & GMAW & 2 & 4 & $122-126$ & 23 & 2.22 & 2.73 & 1.05 \\
\hline & Inconel 82 & GMAW & 3 & 4 & $122-126$ & 23 & 1.81 & 3.24 & 0.89 \\
\hline \multirow{4}{*}{ Four Layer } & $\mathrm{Ni}-\mathrm{Fe}$ alloy & GTAW & 1 & 4 & 100 & $9-11$ & 1.20 & 0.46 & 2.17 \\
\hline & Inconel 82 & GMAW & 2 & 4 & $122-126$ & 23 & 2.15 & 2.49 & 1.15 \\
\hline & Inconel 82 & GMAW & 3 & 3 & $122-126$ & 23 & 1.62 & 2.73 & 1.05 \\
\hline & Inconel 82 & GMAW & 4 & 4 & $122-126$ & 23 & 1.82 & 2.56 & 1.12 \\
\hline
\end{tabular}
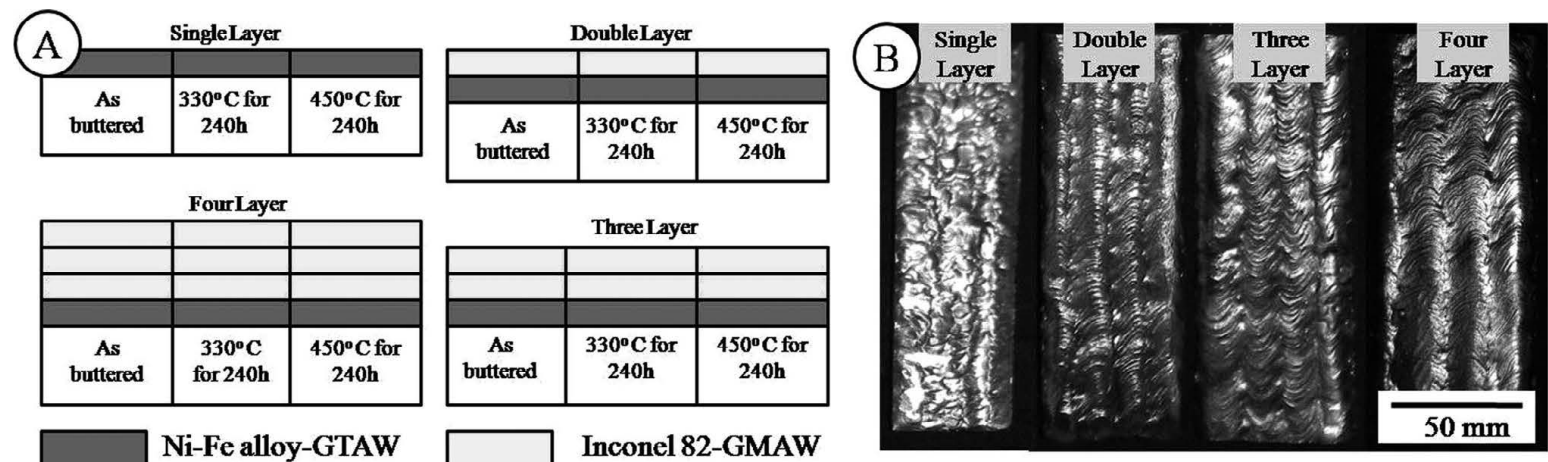

Fig. 1. (A) Schematic of deposited layers and sections for thermal ageing, (B) Buttering layers deposited in sequential order. 
hardness and XRD tests. The chemical composition of filler metals and base metal SA508 Gr.3Cl.1 is presented in Table 2.

\section{Heat Flow Analysis}

The heat flow during deposition of buttering layers using GMAW process was analysed. The heat input and thermal property of buttered material directly regulate the geometry and metallurgical properties of the weld bead. ${ }^{27)}$ Electromagnetic, buoyancy and surface tension forces in the arc weld pool affect the heat distribution and convection. Convection has the impact on the isotherm of weld pool $^{28)}$ and the heat transfer which not only defines the shape of the weld pool but also defines the respective solidification phenomena. The amount of heat generated during buttering affects the metallurgical structure in HAZ. The heat input dictates the depth of HAZ, phase transformation and also the grain size in HAZ. Rosenthal model is useful for prediction of thermal cycles, peak temperature and the estimation of the carbide particles dissolution and HAZ coarsening. ${ }^{29)}$ In the present study, heat flow calculations were made using Rosenthal model. The temperature in depth direction, beneath the weld bead was estimated using 3-diamentional Rosenthal model Eq. (1), with the consideration of thick plate solution. ${ }^{30,31)}$ The mode of heat flow continuously varies with increasing distance from the heat source, therefore the temperature distribution determined by Rosenthal model $^{32)}$ is approximated for thick plate.

$$
\frac{2 \pi(T-T o) k R}{Q}=\exp \left[\frac{-v(R-x)}{2 \alpha}\right]
$$

Table 2. Chemical composition base metal and filler metals.

\begin{tabular}{lcccccccccc}
\hline \multirow{2}{*}{ Condition } & \multicolumn{6}{c}{ Elemental composition in weight percentage (wt\%) } \\
\cline { 2 - 9 } & Layer & $\mathrm{C}$ & $\mathrm{Cr}$ & $\mathrm{Ni}$ & $\mathrm{Fe}$ & $\mathrm{Mn}$ & $\mathrm{Nb}$ & $\mathrm{Mo}$ \\
\hline Base Metal & SA508Gr.3Cl.1 & 0.197 & 0.12 & 0.53 & 96.95 & 1.30 & - & 0.44 \\
Filler Metal & Ni-Fe alloy & 0.025 & - & 53.01 & 43.24 & 0.73 & - & - \\
Filler Metal & Inconel 82 & 0.022 & 20.01 & 71.47 & 2.28 & 2.75 & 2.06 & 0.14 \\
\hline
\end{tabular}

Where $T$ - Peak temperature in $K$

To - Ambient temperature in $K$

$k$ - Base metal thermal conductivity in $\mathrm{J} / \mathrm{ms} K$

$Q$ - Heat transferred from heat source to base metal in watt

$v$ - Welding speed, $\mathrm{m} / \mathrm{sec}$

$\alpha$ - Thermal diffusivity of base metal, $\mathrm{m}^{2} / \mathrm{sec}$

$R$ - Radial distance from the origin in $m=$ $\sqrt{\left(x^{2}+y^{2}+z^{2}\right)}$

The temperatures in depth $(\mathrm{z})$ direction below the weld bead and on the surface across the welding direction are estimated at $2 \mathrm{~mm}$ interval and at the position of thermocouple $(9.2 \mathrm{~mm})$. The estimated temperature is compared with the experimental values and shown in Figs. 2 and 3. Experimental values agree with the predicted values. Figure 2 shows the temperature variation with the time during buttering deposition consisting four passes. The graph is plotted for the depth $9.2 \mathrm{~mm}$ (below the weld) hence, the corresponding temperature for the HAZ is estimated from experimental values. It was assumed that the cooling rate in HAZ and at $9.2 \mathrm{~mm}$ depth were equal.

Isotherms shown in Fig. 3 were repeated three times while depositing subsequent deposit. It is observed that, the

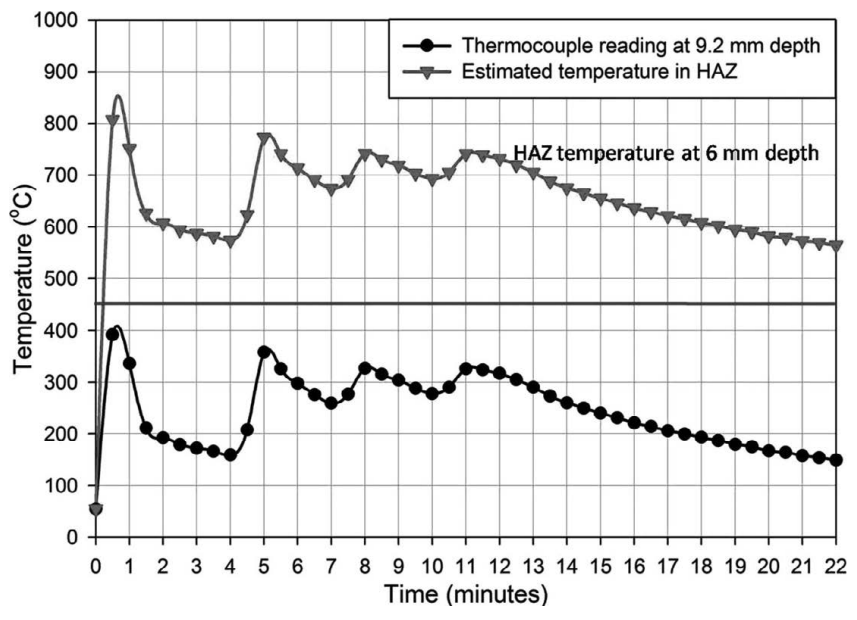

Fig. 2. Time and temperature at $9.2 \mathrm{~mm}$ depth of thermocouple and estimated value in HAZ for second layer of GMAW with four passes.

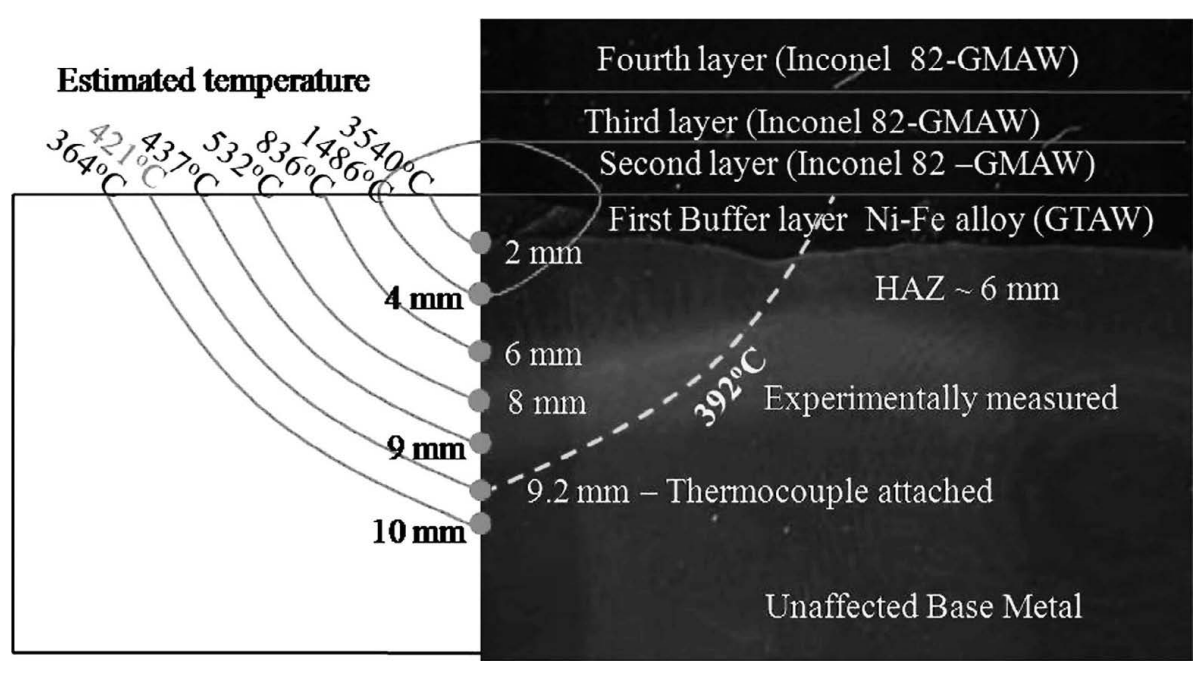

Fig. 3. Estimated and experimental Isotherms during buttering of second layer. 

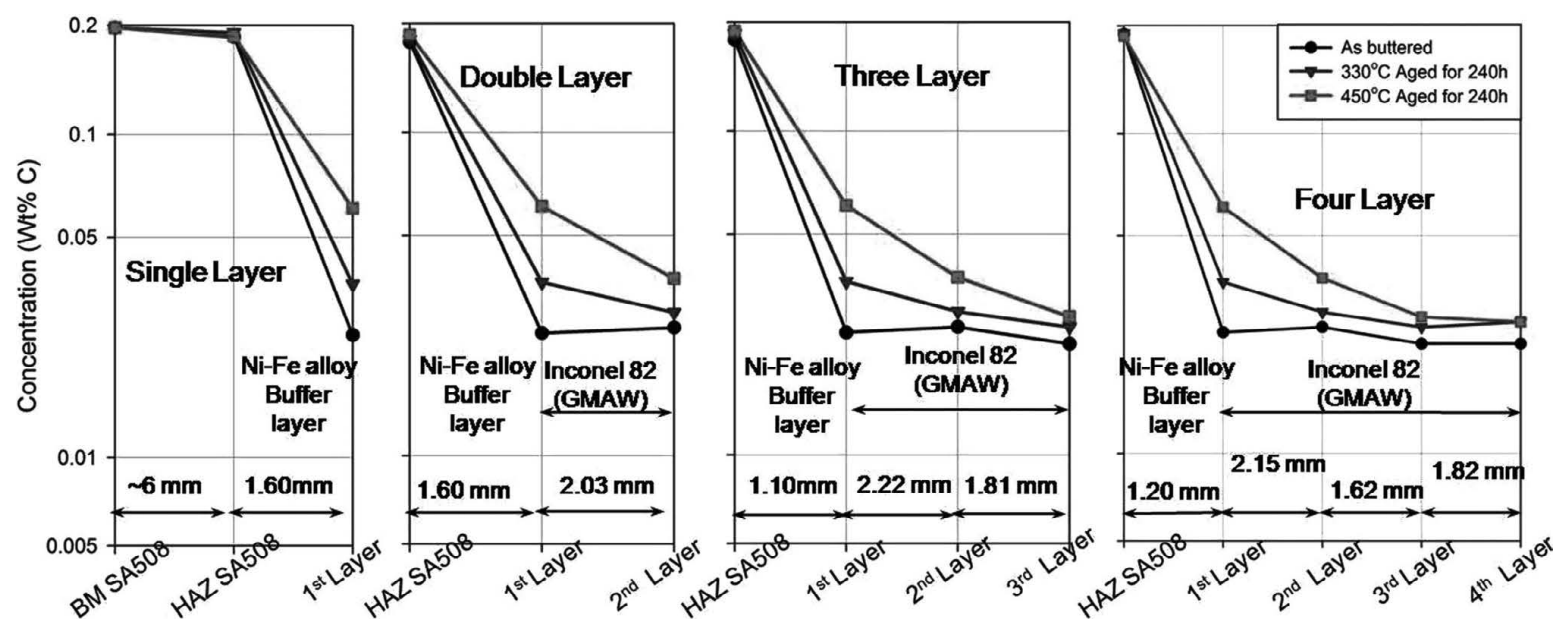

Fig. 4. Carbon wt $\%$ in each layer of buttering and $\mathrm{HAZ}$ (SA508 Gr.3 Cl.1) for as-buttered, $330^{\circ} \mathrm{C}$ and $450^{\circ} \mathrm{C}$ with 240 hour thermally aged, results measured with optical emission spectrometer.

isotherm is shifted in upward direction every time, with the distance of deposited layer thickness. Hence the tempering of HAZ as well as previously deposited layers could have occured according to the shifted isotherms. Coarse grained HAZ is not severe due to the presence of buffer and buttering layers prior to HAZ of substrate which undergoes recur tempering by subsequent depositions. From Fig. 3, it is observed that, the temperature attained at the depth of $9 \mathrm{~mm}$ is $437^{\circ} \mathrm{C}$ and hence there is a possibility for carbide precipitation in this region. Since sufficient amount of chromium is not present in ferritic steel to promote carbide precipitation, the increased activity gradient of carbon may lead to the phase transformation ${ }^{24)}$ in this zone. It is clear from Fig. 3 that the HAZ of the ferritic steel is subjected to a temperture above $550^{\circ} \mathrm{C}$ for a duration of 22 minutes. This duration is sufficient enough to induce phase transformation in HAZ which in turn can cause migration of carbon in this zone.

\section{Chemical Composition and Martensite Formation Analysis}

The chemical compositions of all (as-buttered and thermally aged) specimens were measured with their respective HAZ. The carbon content for all samples is shown in Fig. 4. The carbon content in HAZ of SA508 Gr.3 Cl.1 has been observed to be remaining same in each thermally aged condition. This indicates that there is no significant effect of thermal ageing on carbon migration from HAZ. The significant change in carbon content in buffer (first layer) and subsequent buttering layers was observed at thermally aged conditions. This effect is more pronounced at $450^{\circ} \mathrm{C}$ up to third layer only, and for fourth layer negligible effect has been observed.

Fusion interface chemical analysis was carried out using EPMA. The EPMA traces were recorded from the HAZ SA508 Gr.3 Cl.1 through first buffer layer of Ni-Fe alloy to the second buttering layer of Inconel 82 with the interval of $11 \mu \mathrm{m}$ for a length of $891 \mu \mathrm{m}$. The back scatter electron (BSE) image with black horizontal line indicates the EPMA traces as shown in Fig. 5. The variation in major alloying element $(\mathrm{Cr}, \mathrm{Fe}$, and $\mathrm{Ni})$ across the interfaces using EPMA and for subsequent layers using Optical Emission Spectroscopy (OES) is shown in Fig. 6. The SA508 Gr.3Cl.1 and

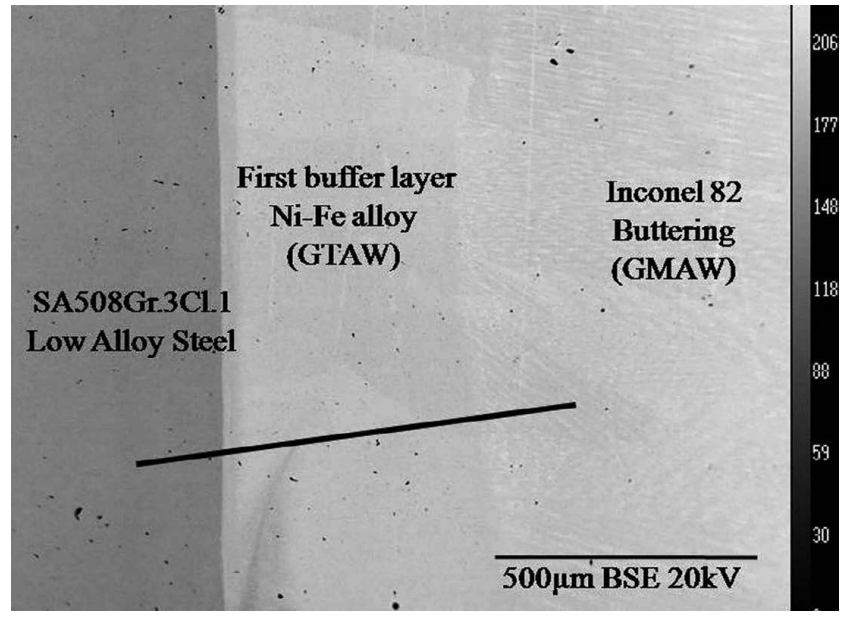

Fig. 5. BSE image of EPMA trace for $891 \mu \mathrm{m}$ at the fusion interface starting from HAZ of ferritic steel to second of Inconel 82 .

Inconel 82 were exhibiting extreme variations in chemical composition. This sharp composition gradient is significantly reduced with the use of first buffer layer of $\mathrm{Ni}-\mathrm{Fe}$ alloy. Significant composition gradient attained with $\mathrm{Ni}-\mathrm{Fe}$ buffer layer is shown in Fig. 6. The variation in chemical composition of SA508 Gr.3Cl.1, Ni-Fe and Inconel 82 has same composition gradient ${ }^{15)}$ in partially mixed zone (PMZ) where the metal diluted partially during deposition near to fusion boundary. Within PMZ, changes in chemical composition increases the hardenability of deposited metal due to formation of martensite as an effect of cooling rate during solidification. ${ }^{3,15,25,33)}$ Alloying elements such as $\mathrm{C}, \mathrm{Mn}, \mathrm{Ni}$, $\mathrm{Cr}$, and $\mathrm{Mo}^{15)}$ have actively participated in the formation of martensite. The $\mathrm{Cr}, \mathrm{Fe}$ and Ni were measured using EPMA, while the light element carbon and low concentration elements Mn and Mo were not possible to measure. The concentration of these elements was estimated on the basis of dilution of major element $\mathrm{Fe}$ and $\mathrm{Ni}$ in PMZ using EPMA. ${ }^{15,25,33,34)}$ Variation in dilution of $\mathrm{Fe}$ and $\mathrm{Ni}$ within PMZ has been used along with nominal concentration of element in SA508 Gr.3Cl.1 and filler metals to estimate the $\mathrm{C}, \mathrm{Mn}$, and Mo by back-calculation. ${ }^{15,25,33,34)}$ The assumption has been made that, the $\mathrm{C}, \mathrm{Mn}$, and Mo would be mixed 


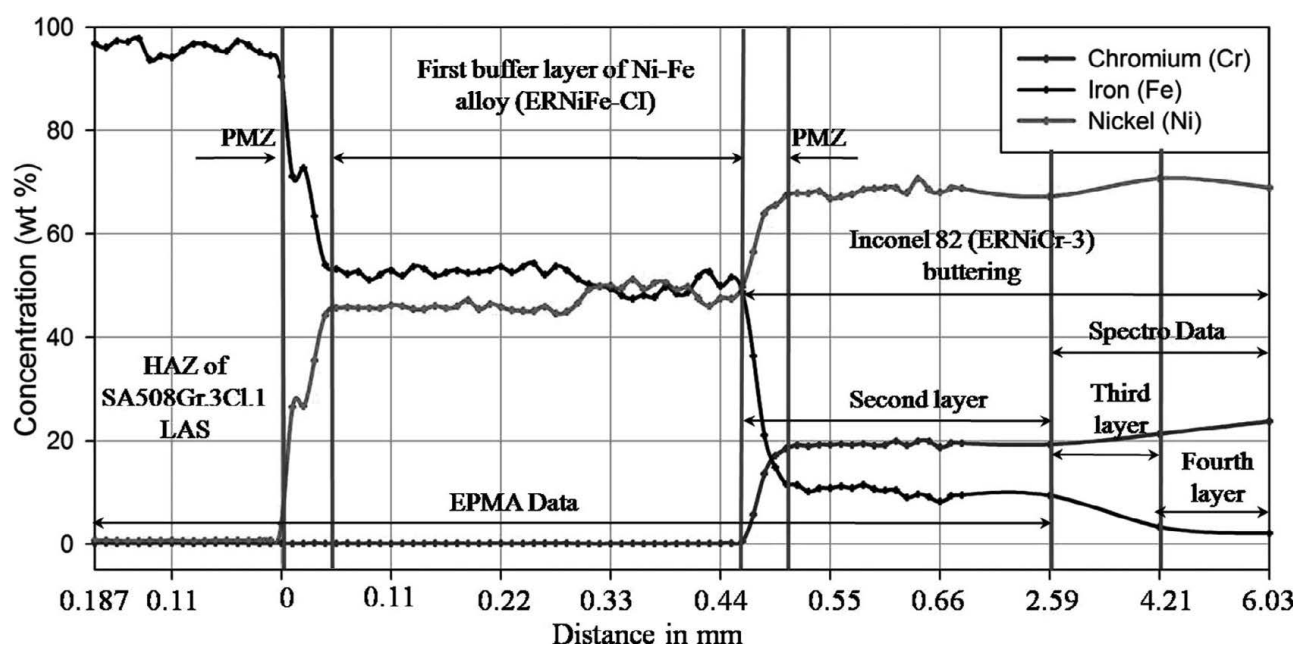

Fig. 6. Major alloying element variations by EPMA at weld interfaces and OES at subsequent buttering layers.

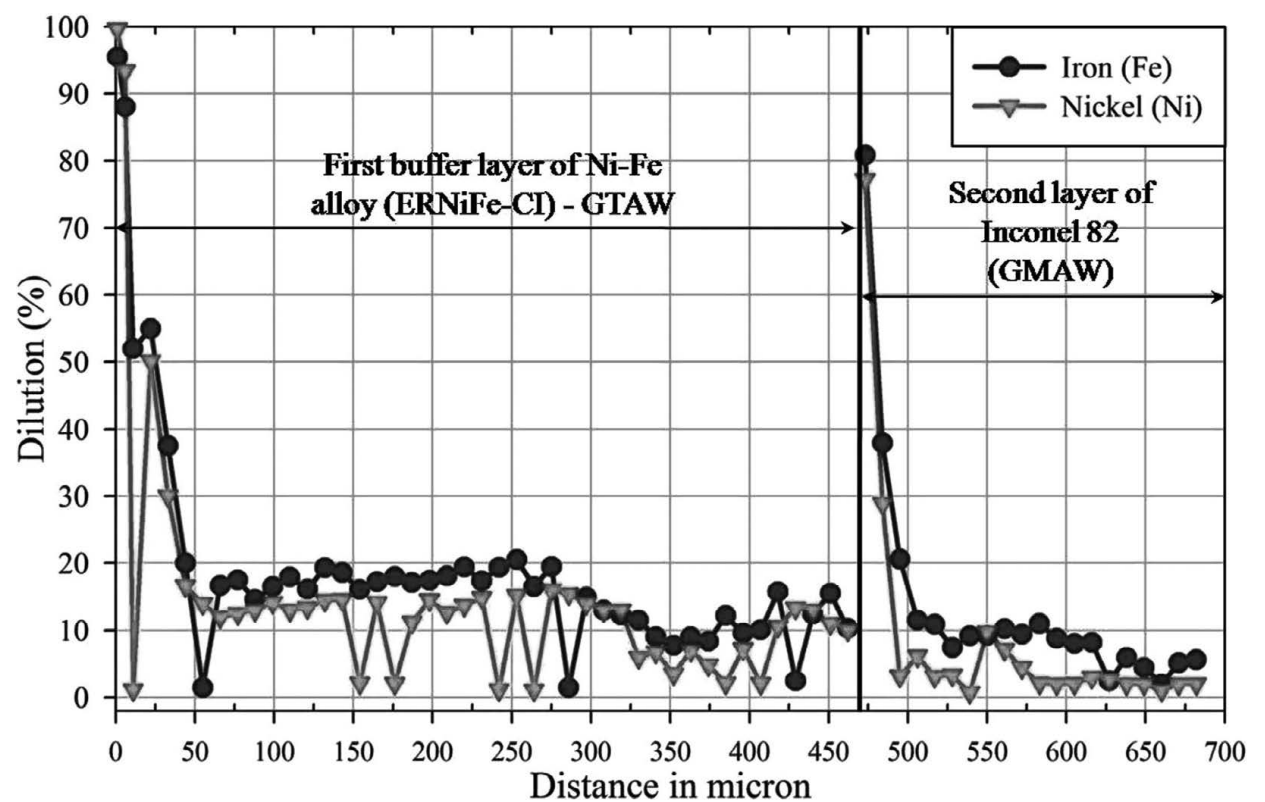

Fig. 7. Variation in dilution of Fe and Ni across the PMZ of SA508 Gr.3Cl.1 - Ni-Fe alloy and Ni-Fe alloy - Inconel 82.

in $\mathrm{PMZ}$ in the same proportion as major element $\mathrm{Ni}$ and $\mathrm{Fe}$.

Variation in dilution $(d)$ has been estimated by Eq. (2) with the help of EPMA trace data.

$$
d=\frac{C_{P M Z}-C_{F M}}{C_{B M}-C_{F M}}
$$

Where $d$ indicates the dilution, $C_{P M Z}$ indicates the concentration of element in PMZ, $C_{F M}$ indicates the nominal concentration of elements in the filler metal, and $C_{B M}$ is the nominal concentration of elements in base metal. The $C_{F M}$ and $C_{B M}$ values for major elements $\mathrm{Fe}$ and $\mathrm{Ni}$ were measured by OES and the $C_{P M Z}$ values of these elements have been obtained from EPMA data as shown in Fig. 6. The percentage dilution in PMZ from OES and EPMA at each position for major element $\mathrm{Fe}$ and $\mathrm{Ni}$ is shown in Fig. 7. The values of $\mathrm{C}, \mathrm{Mn}$, and Mo concentration have been determined using the Eq. (3) and variation in dilution. The known compositions of elements with the maximum and minimum dilution of major elements have been used in Eq. (3) to estimate the $\mathrm{C}, \mathrm{Mn}$, and Mo concentrations in the PMZ.

$$
C_{P M Z}=\% D C_{B M}+(1-\% D) C_{F M}
$$

The estimated values of carbon in PMZ are shown in Fig. 8. The low concentration elements $\mathrm{Mn}$ and Mo were accounted for calculation only. The SA508 Gr.3Cl.1 was substrate for deposition of first buffer layer with filler metal $\mathrm{Ni}-\mathrm{Fe}$ alloy while, for second buttering layer of Inconel 82, first buffer layer was substrate. The calculation of martensite start $\left(M_{S}\right)$ temperature as per Gooch and Dupont ${ }^{15,25,33,34)}$ is given by Eq. (4).

$$
\begin{aligned}
M_{S}\left({ }^{\circ} \mathrm{C}\right)= & 540-(497 \% \mathrm{C}+6.3 \% \mathrm{Mn} \\
& +36.3 \% \mathrm{Ni}+10.8 \% \mathrm{Cr}+46.6 \% \mathrm{Mo})
\end{aligned}
$$

The variations in maximum and minimum martensite start $\left(M_{s}\right)$ temperature in PMZ with distance across interfaces are shown in Fig. 9. The estimated thickness of martensite is $\sim 7.5 \mu \mathrm{m}$ at $\mathrm{SA} 508 \mathrm{Gr} .3 \mathrm{Cl} .1-\mathrm{Ni}-\mathrm{Fe}$ alloy interface, while it is $\sim 2.5 \mu \mathrm{m}$ at $\mathrm{Ni}-\mathrm{Fe}$ alloy - Inconel 82 interface. The thicknesses of martensite layer at both interfaces are varying due to changes in chemical composition of the filler metals 


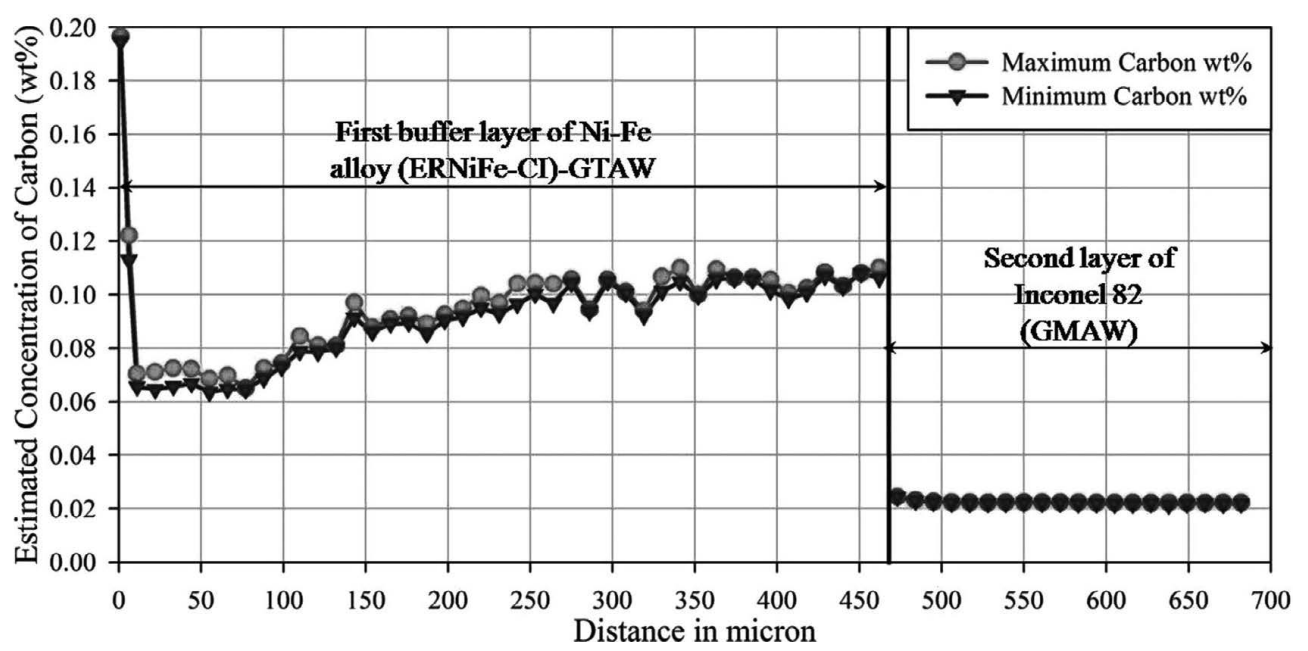

Fig. 8. Estimated concentration of carbon across the PMZ of first buffer layer and second buttering layer with max and min values estimated from dilution of $\mathrm{Fe}$ and $\mathrm{Ni}$.

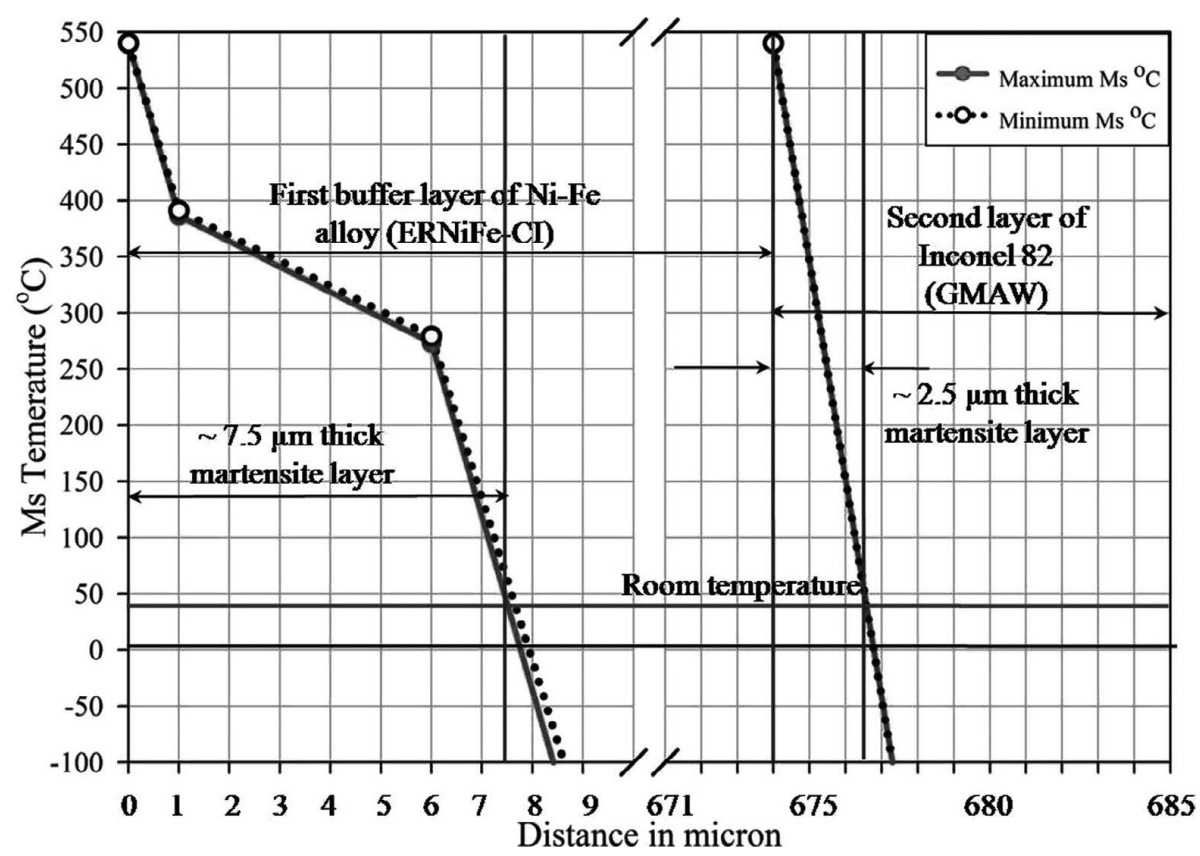

Fig. 9. Max and min martensite start $\left(\mathrm{M}_{\mathrm{s}}\right)$ temperature variation across the fusion boundaries of $\mathrm{SA} 508 \mathrm{Gr} .3 \mathrm{Cl} .1-\mathrm{Ni}-\mathrm{Fe}$ alloy and $\mathrm{Ni}-\mathrm{Fe}$ alloy - Inconel 82.

and dilution owing to process variation. As the martensitic structure is hard and brittle, it tends to reduce the fracture toughness at the interface which is highly undesirable.

\section{Carbon Diffusion Analysis}

The DMW joints are often associated with the carbon migration problem. Carbon diffusion process involves decomposition of carbides in SA508 Gr.3Cl.1 and diffusion of carbon from SA508 Gr.3Cl.1 to Ni-Fe alloy/Inconel 82 takes place at interface. The driving force for diffusion is the carbon activity gradient between low $\mathrm{Cr}$ content (SA508 Gr.3Cl.1) and high $\mathrm{Cr}$ content (Inconel 82). Therefore, the buffer layer of Ni-Fe alloy composition would restrict the carbon to migrate owing to absence of carbon activity gradient as there is no Cr. Increasing the Ni content of filler metal alters the carbon solubility, makes carbide less stable, changes diffusivity and in general retards carbon migration from ferritic material. ${ }^{3)}$ Ni-base filler metals (Inconel 82) cannot completely prevent the formation of soft zone, but it can significantly decrease the growth rate of soft zone. The higher $\mathrm{Cr}$ content acts as a driving force to support formation of soft zone. ${ }^{11)}$ The carbon content in HAZ and respective buttering layers in all the thermally aged samples are shown in Fig. 4. HAZ of samples have not revealed the decarburised soft zone; hence the absence of $\mathrm{Cr}$ in buffer layer cannot provide driving force for carbon migration. The Groube integration assumes that the concentration gradient is symmetrical about an interface between two components and that the diffusion coefficient does not vary with concentration. This assumption is suitable in small concentration gradient system. Even though the Groube solution assumes that $D$ is independent of concentration, it can be used with reasonable accuracy for different buttering layers, when $D$ is a function of $C$, by choosing $C_{1}$ and $C_{2}$ within narrow composition range for any one diffusion couple. In the pres- 
ent study, it was assumed that during thermal ageing the composition of layers, forming the diffusion couple would remain constant independent of the layer thickness. This assumption is valid for the as buttered condition and the thermal ageing.

The diffusivity ${ }^{35)}$ of carbon has been determined using Groube solution (Eq. (5)) for diffusion couple.

$$
C(x, t)-C_{1}=\frac{C_{2}-C_{1}}{2}\left[1-\operatorname{erf}\left(\frac{x}{2 \sqrt{D t}}\right)\right]
$$

Where $C(x, t)$ is the known weight percentage of carbon, $C_{2}$ is the higher concentration of carbon, $C_{1}$ is the lower concentration of carbon, $D$ represents the diffusivity of carbon in $\mathrm{m}^{2} / \mathrm{s}, x$ is the distance in $m$ at which measurement made and $t$ is the time in sec. The temperature of HAZ SA508 Gr.3Cl.1 measured during buttering was found to be more than $450^{\circ} \mathrm{C}$ for 22 minutes, which has been used for calculation of the diffusivity for buttered condition. The diffusivities of carbon are calculated for each layer under buttered and thermally aged conditions and the results are presented in Table 3.

In as buttered condition, diffusivity of carbon $(D)$ from SA508 Gr.3Cl.1 to first buffer layer is observed to be very less compared to the subsequent buttering layers. Inverse diffusion is evident in fourth layer of Inconel 82 buttering, which indicates no further carbon migration possible from fourth layer. The diffusivity from SA508 Gr.3Cl.1 - Ni-Fe alloy is observed to be very less in thermally aged condition. The diffusion of carbon is more pronounced in as buttered condition. Bose ${ }^{35)}$ has reported on the diffusion of carbon in Nickel. Using the diffusion coefficient $\left(D_{o}\right)$ and activation energy $(Q),{ }^{35,36)}$ the diffusivity of carbon in Nickel at $330^{\circ} \mathrm{C}$ and $450^{\circ} \mathrm{C}$ was determined using the temperature dependence Eq. (6) of diffusivity.

$$
D=D_{o} \exp \left(-\frac{Q}{R T}\right)
$$

Where the $D$ is diffusivity of carbon, $D_{o}$ is the diffusion coefficient in $\mathrm{m}^{2} / \mathrm{s}, Q$ represents the activation energy in $\mathrm{kJ} / \mathrm{mol}, R$ is the gas constant in $J / \mathrm{Kmol}$, and $T$ is the temperature in Kelvin. The diffusivity of carbon in Nickel at $330^{\circ} \mathrm{C}$ and $450^{\circ} \mathrm{C}$ was found to be $8.90 \times 10^{-18} \mathrm{~m}^{2} / \mathrm{s}$ and $8.58 \times 10^{-16} \mathrm{~m}^{2} / \mathrm{s}$ respectively. The diffusivities for $\mathrm{Ni}-\mathrm{Fe}$ alloy and Inconel 82 are higher than the diffusivity of car-

Table 3. Diffusivity $(D)$ of carbon in each buttering layer and thermally aged conditions.

\begin{tabular}{cccc}
\hline & \multicolumn{3}{c}{ Diffusivity (D) in $\mathrm{m}^{2} \mathrm{~s}^{-1}$} \\
\cline { 2 - 4 } & As buttered & $330^{\circ} \mathrm{C}$ aged & $450^{\circ} \mathrm{C}$ aged \\
\hline $\begin{array}{c}\text { Ferritic steel (SA508) - } \\
\text { First buffer layer (Ni-Fe alloy) }\end{array}$ & $3.24 \times 10^{-11}$ & $6.24 \times 10^{-13}$ & $2.22 \times 10^{-12}$ \\
$\begin{array}{c}\text { First layer (Ni-Fe alloy) - } \\
\text { Second layer (Inconel 82) }\end{array}$ & $\uparrow 3.38 \times 10^{-9}$ & 0 (nil) & $2.78 \times 10^{-11}$ \\
$\begin{array}{c}\text { Second layer (Inconel 82) - } \\
\text { Third layer (Inconel 82) }\end{array}$ & $2.69 \times 10^{-9}$ & $\uparrow 5.83 \times 10^{-11}$ & $2.94 \times 10^{-11}$ \\
$\begin{array}{c}\text { Third layer (Inconel 82) - } \\
\text { Fourth layer (Inconel 82) }\end{array}$ & $\uparrow 8.00 \times 10^{-11}$ & $\uparrow 2.70 \times 10^{-12}$ & $\uparrow 2.02 \times 10^{-12}$ \\
\hline$\uparrow$ - indicates inverse diffusion & & & \\
\hline
\end{tabular}

bon in pure $\mathrm{Ni}$. Owing to $\mathrm{Fe}$ and $\mathrm{Cr}$ in $\mathrm{Ni}-\mathrm{Fe}$ alloy and Inconel 82 respectively, the carbide precipitation could increase the diffusivity than pure Ni. Sudha et al. ${ }^{37)}$ reported on the diffusion coefficient of carbon $(D)$ for $9 \mathrm{Cr}-1 \mathrm{Mo}$ hard zone as $2.95 \times 10^{-13} \mathrm{~m}^{2} / \mathrm{s}$ and $2.25 \mathrm{Cr}-1$ Mo steel soft zone as $2.85 \times 10^{-9} \mathrm{~m}^{2} / \mathrm{s}$. The diffusivities in $\mathrm{Ni}-\mathrm{Fe}$ alloy are observed to be very less than the soft zone diffusivity of $2.25 \mathrm{Cr}-1 \mathrm{Mo}$ steel interface.

\section{Micro-hardness Evaluation}

The Vickers micro-hardness of the HAZ and buttering layers of the each specimen was evaluated with 100 and $10 \mathrm{gf}$ loads. Hardness across the fusion interfaces of SA508 Gr.3Cl.1 - first buffer layer (Ni-Fe alloy) and $\mathrm{Ni}-\mathrm{Fe}$ alloy - second buttering layer (Inconel 82) have been determined. Hardness across the different fusion interfaces for as buttered, thermally aged conditions and PWHT are shown in Fig. 10. Owing to presence of $\mathrm{Nb}$ in Inconel 82 deposit, at higher temperature PWHT the hardness and toughness of deposit could improve. ${ }^{38)}$ Soft zone formation is not significant and formation of hard zone in Ni-Fe layer and interface is due to presence of martensite. Ni-Fe buffer layer evidenced with the lowest hardness across the interfaces with as buttered and thermal ageing conditions. Martensite formation in $\mathrm{Ni}-\mathrm{Fe}$ buffer layer and Inconel 82 buttering layer is more significant with thermal ageing at $450^{\circ} \mathrm{C}$. Owing to PWHT, the hardness variation is not significant across the layers. It decreases the hardness of martensite in PMZ and increases significantly the hardness of Ni-Fe buffer layer and it maintains the hardness equilibrium across the layers. This transformation caused the martensite in PMZ into tempered martensite. The increase in composition gradient owing to higher temperature (PWHT) for $\mathrm{Ni}-\mathrm{Fe}$ buffer layer, the phase transformation is resulted.

\subsection{Microstructure Analysis}

SA508Gr.3Cl.1 ferritic steel has tempered bainitic structure. Disbonding could occur along Type II boundary with Ni-base cladding or buttering. ${ }^{21,25)}$ The substrate of ferritic steel with BCC structure is usually deposited with austenitic Ni-base consumable of FCC structure (Inconel 82) for subsequent welding with austenitic stainless steel. Due to mismatch in crystal structure, instead of epitaxial growth, the wider grains parallel to the fusion line are eventually formed and that is termed as Type II boundary or disbonding. These boundaries are susceptible to the in-service cracking. Owing to composition of $\mathrm{Ni}-\mathrm{Fe}$ buffer layer, the Type II boundaries and disbonding were not revealed in either $\mathrm{Ni}-\mathrm{Fe}$ alloy buffer layer or in Inconel 82 buttering despite the epitaxial growth from ferritic steel is revealed. Figure 11 shows the interface of ferritic steel with coarse grained heat affected zone (CGHAZ) of bainitic structure. The carbon rich zone indicates the saturation of carbon in HAZ and no significant carbon migration takes place from SA508 Gr.3Cl.1 to buffer layer of Ni-Fe alloy. The dendritic and cellular structure is observed with $\mathrm{Ni}-\mathrm{Fe}$ alloy buffer layer and the sharp fusion boundary exists at the interface with Inconel 82 buttering, as shown in Fig. 12.

Significant changes in buttering layers were not observed for thermally aged conditions. The cellular and equiaxed 


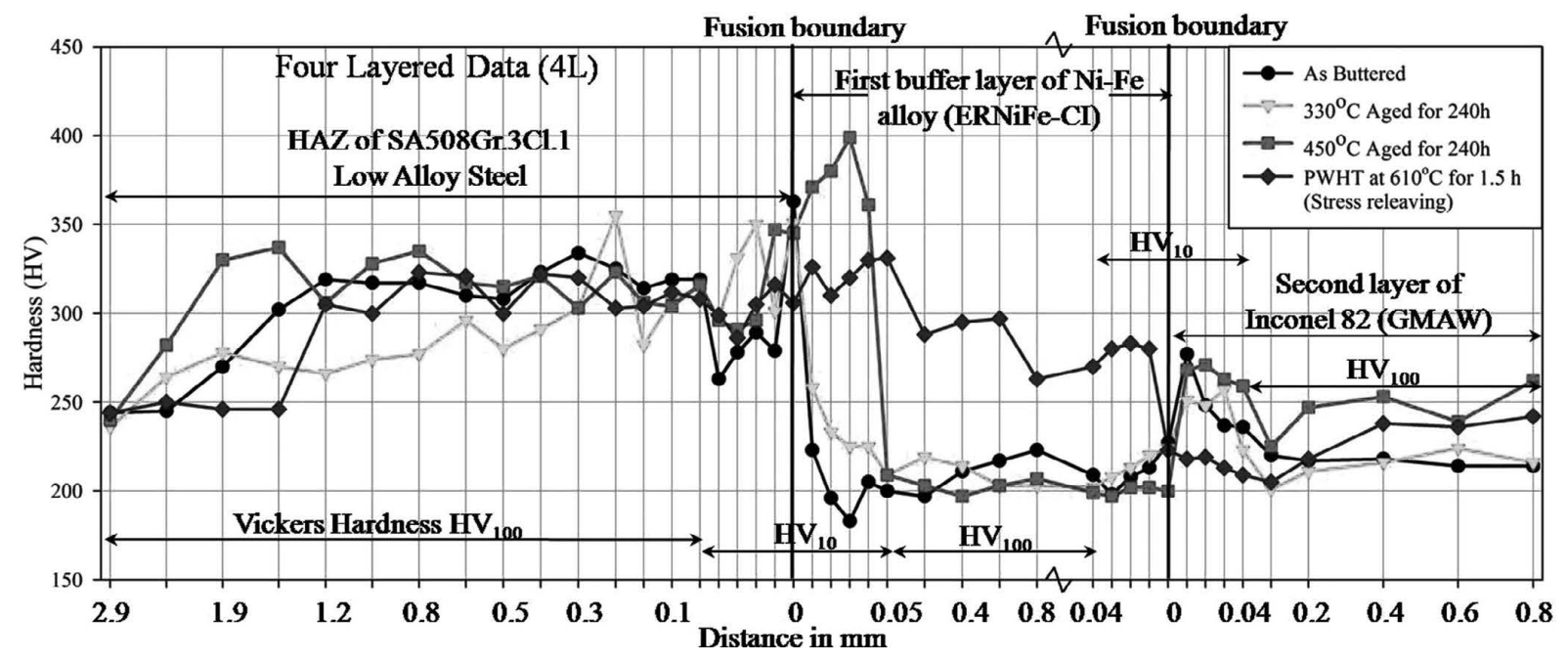

Fig. 10. Micro-hardness of four layered buttering deposit across the fusion boundaries including HAZ of SA508 Gr.3Cl.1, first buffer layer (Ni-Fe alloy) and second buttering layer of Inconel 82.

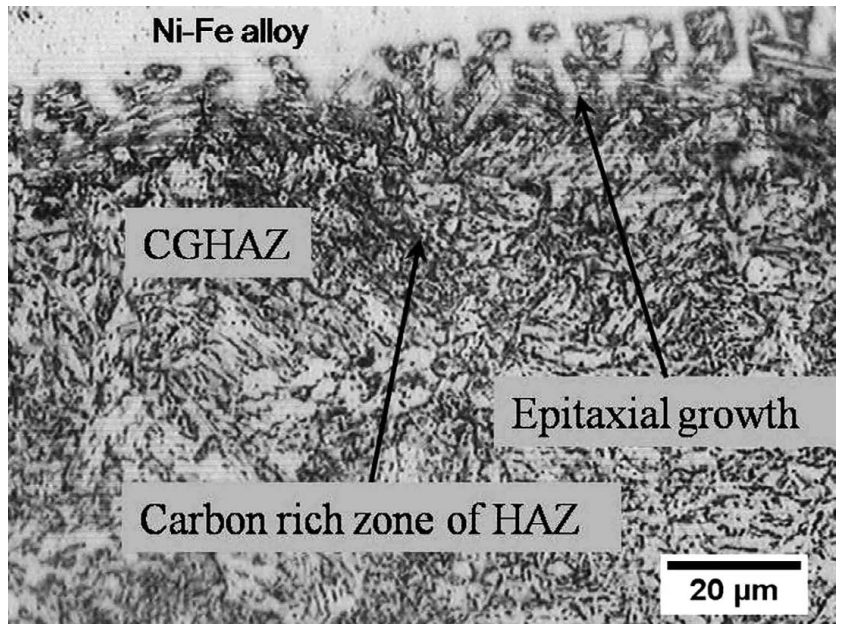

Fig. 11. Fusion interface of SA508 Gr.3Cl.1 - Ni-Fe alloy showing $\mathrm{CG}$ bainitic $\mathrm{HAZ}$ and carbon rich zone.

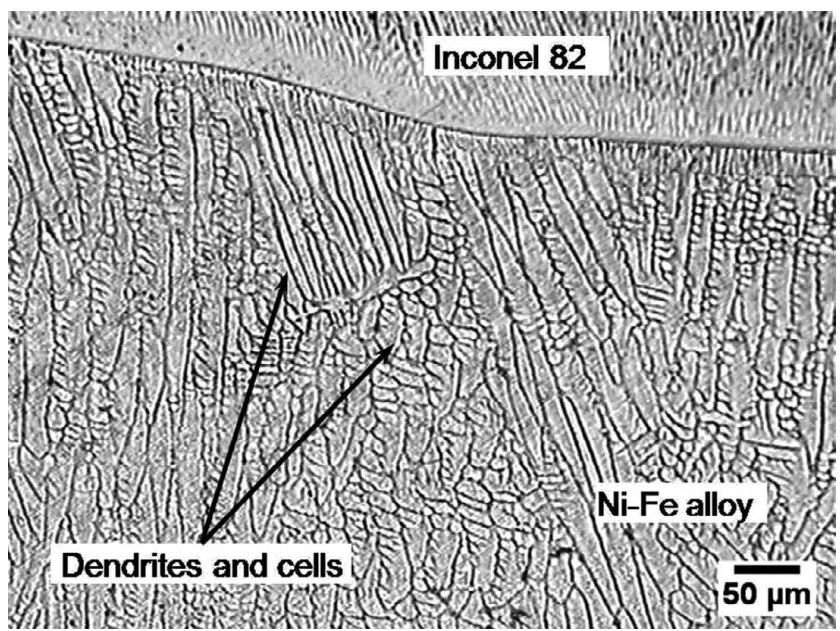

Fig. 12. Interior of $\mathrm{Ni}-\mathrm{Fe}$ buffer layer and interface with Inconel 82 , arrow indicates the cells and dendrites.

dendrites were developed in the direction of cooling, and complete austenitic structure of Inconel 82 is seen in buttering layer and the same is shown in Fig. 13. This structure

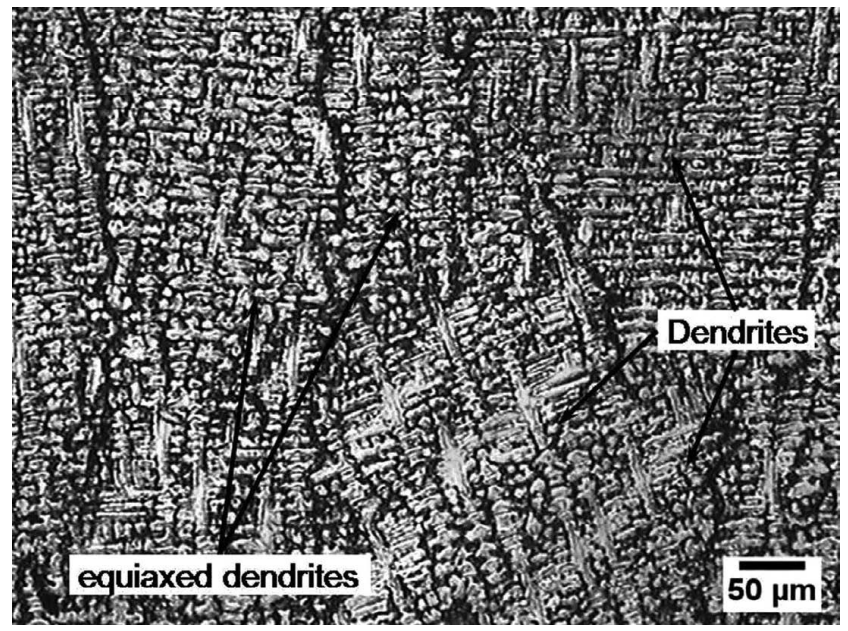

Fig. 13. Interior of Inconel 82 buttering, shows the dendritic structure with fully austenitic equiaxed dendrites.

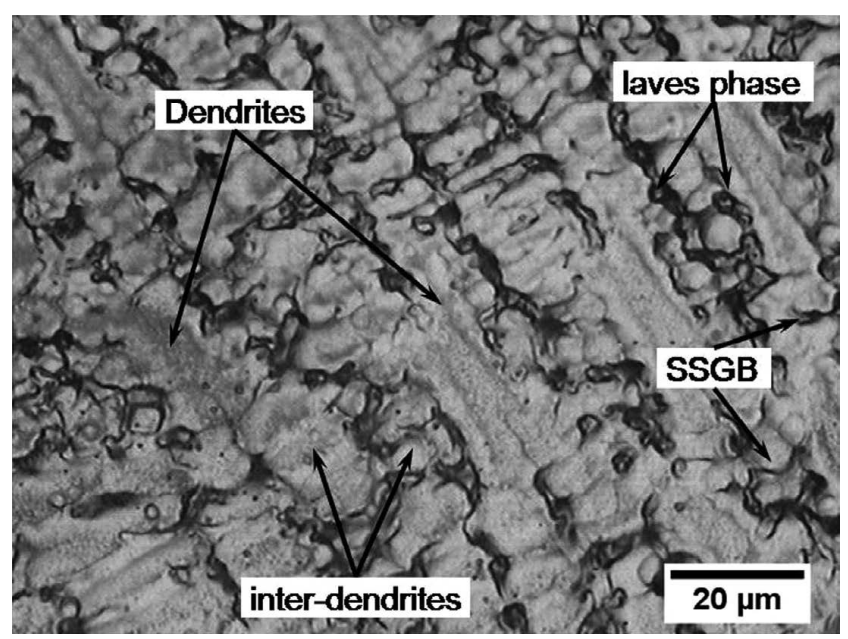

Fig. 14. Interior of Inconel 82 buttering, arrows indicating the dendritic, inter-dendritic regions, SSGB and the laves phases.

had not undergone any allotropic transformation during deposition and respective cooling. ${ }^{39)}$ It remains austenitic, therefore in each layer of buttering the hardness is not 

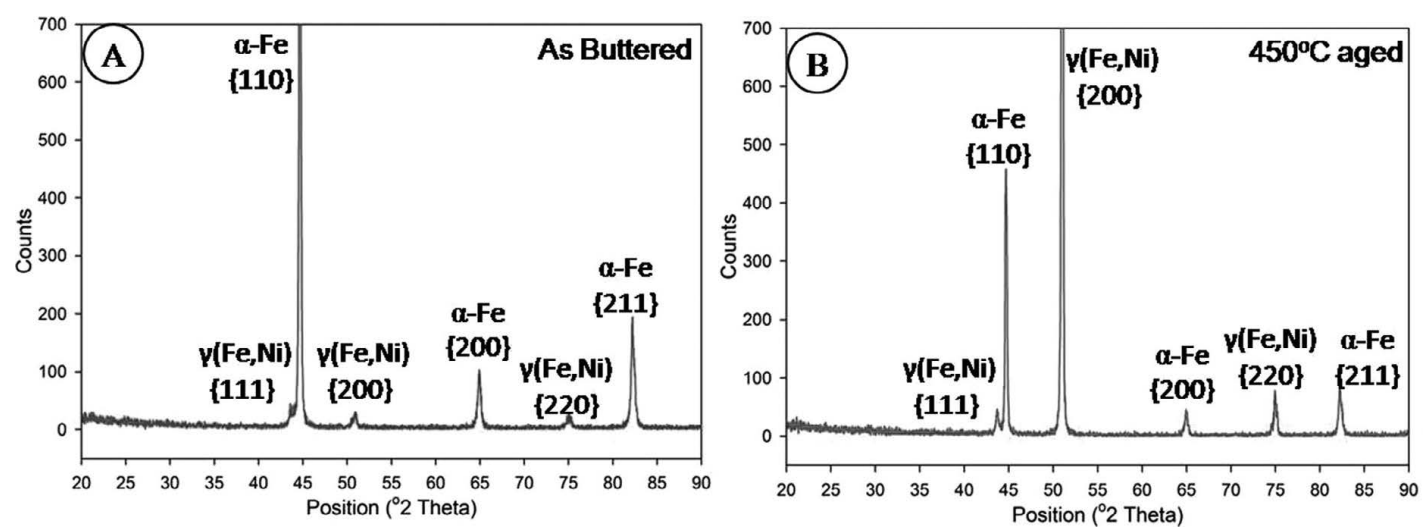

Fig. 15. XRD peaks of four layered (A) as buttered specimen and (B) $450^{\circ} \mathrm{C}$ thermally aged specimen.

expected to vary. ${ }^{2,7)}$ The microstructure of the dendrites and inter-dendrites is shown in Fig. 14. Laves phases are observed at the solidification subgrain boundary (SSGB). The arrows indicate the SSGB, associated laves phases, dendritic and interdendritic structures. The buttering deposit simply with Inconel 82 is susceptible for hard zone owing to formation chromium carbide precipitates but the microstructure does not show presence of chromium carbide and other secondary phase precipitates in buttering.

\subsection{XRD Analysis}

X-ray diffraction for phases identification has been conducted on four layered specimens for identification and presence of the undesirable carbide precipitates in the deposit. The details of peaks of as buttered and thermally aged condition are shown in Figs. 15(A) and 15(B) with different phases at respective $2 \theta$ positions. The XRD pattern is obtained with Phillip X'Pert PRO thin film X-ray diffractometer. The step size of $0.05(2 \theta)$ have been used for the $2 \theta$ range of $20^{\circ}$ to $90^{\circ}$. The XRD patterns were analysed with the JCPDS-ICDD software using PCPDFWIN program. The PDF numbers of the respective phases and/or compounds are also referred for the matched peaks. The phases observed in microstructure evolution were confirmed using XRD analysis. The analysis was conducted in the first buffer layer (Ni-Fe layer with dilution effect) adjecent to the ferritic steel using the cross section of deposits. $\mathrm{Ni}-\mathrm{Fe}$ alloy mixes with substrate (ferritic steel) during deposition of first buffer layer and Inconel 82 mixes with $\mathrm{Ni}-\mathrm{Fe}$ alloy during second layer deposition. Hence, the XRD analysis for Ni$\mathrm{Fe}$ alloy layer which was diluted with ferritic steel substrate and mixed with Inconel 82 was carried out. As buttered and $450^{\circ} \mathrm{C}$ thermally aged specimens were analysed using XRD for the Ni-Fe buffer layer. The $\gamma(\mathrm{Fe}, \mathrm{Ni})$ phase (PDF no: $47-$ $1417)$ with diffracted plane $\{111\}$ was observed. The $\alpha$-Fe (PDF no: 06-0696) with diffracted plane $\{110\}$ was confirmed. The austenite $\gamma(\mathrm{Fe}, \mathrm{Ni})$ (PDF no: 47-1417) was observed with diffracted plane $\{200\}$. The $\alpha$-Fe phase (PDF no: 06-0696) with diffracted plane $\{200\}$ was confirmed. The $\alpha$-Fe phase (PDF no: 06-0696) with diffracted plane $\{211\}$ was also confirmed in the deposits. The Fig. 15 shows the characteristics reflexes of the coexisting $\gamma_{\mathrm{fcc}}-$ austenite and $\alpha_{\mathrm{bcc}}-$ ferrite phases. The $\alpha_{\mathrm{bcc}}$ also indicates the presence of $\alpha^{\prime}$ bcc - martensite phase. ${ }^{40)}$ The presence of martensite formation at the fusion boundary of ferritic steel substrate and buffer layer ( $\mathrm{Ni}-\mathrm{Fe}$ ) was also confirmed with micro-hardness evaluation. The similar phases were observed in both as buttered and thermally aged specimens with the varying intensity of the counts. No significant variations were observed in the phases as an effect of the thermal ageing. This signifies that the same phase structure of as buttered condition can persist upto $450^{\circ} \mathrm{C}$ without formation of carbide precipitations. In general, such buttering deposits are highly desirable for dissimilar metal weld joints due to non-existance of hard phases in the buttering. The peaks identification is confirmed with the peaks gained by Baltusnikas and Levinskas ${ }^{41)}$ and Sireesha et al. ${ }^{8)}$ The undesirable phases such as carbide precipitates are not identified in any of the specimen.

\section{Conclusion}

- GMAW process for buttering deposition is confirmed as the cost effective alternative over the time-consuming and expensive GTAW process.

- $\mathrm{Ni}-\mathrm{Fe}$ alloy reduces the composition gradient and carbon migration between SA508Gr.3Cl.1 and Inconel 82.

- Nonexistence of decarburised zone and carbide precipitation justifies the restraint of carbon diffusion.

- The width of martensite formation at the interfaces of $\mathrm{Ni}-\mathrm{Fe}$ alloy with SA508 Gr.3 Cl.1 and Inconel 82 is limited to about $7.5 \mu \mathrm{m}$ and $2.5 \mu \mathrm{m}$ respectively. Subsequent PWHT resulted in reduction in hardness owing to the formation of tempered martensite and favourable hardness profile could be form across the weldment zones.

- Four layered deposit around $6 \mathrm{~mm}$ thickness is required for effectiveness of buttering deposition in view of carbon migration.

- Diffusivity of carbon from SA508Gr.3Cl.1 is more significant during deposition of layers.

- Inverse diffusion could completely retard the carbon migration from SA508 Gr.3Cl.1 to buttering/weld metal.

\section{Acknowledgement}

The authors thank the Board of Research in Nuclear Sciences, Department of Atomic Energy, for financial support for the work. Authors are also thankful to the Defence Metallurgical Research Laboratory, Ministry of Defence, for providing EPMA facility to carry out the diffusion related study. 


\section{REFERENCES}

1) R. Miteva and N. G. Taylor: NESC Report, Institute for Energy, Netherland, (2006).

2) A. K. Bhaduri, S. Venkadesan, P. Rodriguez and P. G. Mukunda: Int J. Pres. Ves. Pip., 58 (1994), No. 3, 251.

3) C. D. Lundin: Weld. J., 61 (1982), No. 2, 58s.

4) M. Sireesha, S. K. Albert, V. Shankar and S. Sundaresan: J. Nucl. Mater., 279 (2000), No. 1, 65.

5) A. Celik and A. Alsaran: Mater. Charact., 43 (1999), No. 5, 311.

6) M. Sireesha, V. Shankar, S. K. Albert and S. Sundaresan: Mater. Sci. Eng. A, 92 (2000), No. 1, 74.

7) C. R. Das, A. K. Bhaduri, G. Srinivasan, V. Shankar and S. Mathew: J. Mater. Process. Technol., 209 (2009), No. 3, 1428.

8) M. Sireesha, S. K. Albert and S. Sundarasan: Metall. Mater. Trans. A, 36A (2005), 1495.

9) A. Joseph, S. K. Rai, T. Jayakumar and N. Murugan: Int. J. Pres. Ves. Pip., 82 (2005), No. 9, 700.

10) C. Sudha, A. L. E. Terrance, S. K. Albert and M. Vijayalakshmi: $J$. Nucl. Mater., 302 (2002), No. 2-3, 193.

11) Y. Y. Ying, S. R. Kae, S. R. Haur and C. Chun: J. Mater. Sci. Lett., 20 (2001), No. 15, 1429.

12) C. Sudha, V. T. Paul, A. L. E. Terrance, S. Saroja and M. Vijayalakshmi Weld. J., 85 (2006), No. 4, 71s

13) R. Anand, C. Sudha, V. T. Paul and S. Saroja: Weld. J., 89 (2010), No. 4, 65s.

14) J. N. DuPont, S. Babu and S. Liu: Metall. Mater. Trans. A, 44A (2013), 3385.

15) J. N. Dupont and C. S. Kusko: Weld. J., 86 (2007), No. 2, 51s.

16) C. Jang, J. Lee, J. Sung Kim and T. Eun Jin: Int. J. Pres. Ves. Pip., 85 (2008), No. 9, 635.

17) J. W. Kim, K. Lee, J. S. Kim and T. S. Byun: J. Nucl. Mater., 384 (2009), No. 3, 212.

18) H. P. Seifert, S. Ritter, T. Shoji and Q. J. Peng: J. Nucl. Mater., 378 (2008), 197.

19) K. H. Schwalbe, A. Cornec and D. Lidbury: Int. J. Pres. Ves. Pip., 81 (2004), No. 3, 251.

20) M. Sireesha, S. K. Albert and S. Sundaresan: Int. J. Pres. Ves. Pip., 79 (2002), No. 12, 819.
21) T. W. Nelson, J. C. Lippold and M. J. Mills: Weld. J., 79 (2000), No. $10,267 \mathrm{~s}$.

22) Y. K. Yang and S. Kou: Weld. J., 86 (2007), No. 12, 379s.

23) F. G. Caballero, M. K. Miller and C. Garcia-Mateo: Acta Mater., 58 (2010), 2338.

24) G. E. Totten: Steel Heat Treatment: Metallurgy and Technologies, CRC Press, New York, (2007), 833

25) J. N. DuPont, J. C. Lippold and S. D. Kiser: Welding Metallurgy and Weldability of Nickel-base Alloys, Wiley Publications, NJ, (2009), 440.

26) J. C. Lippold and D. J. Kotecki: Welding Metallurgy and Weldability of Stainless Steels, Wiley Publication, NJ, (2005), 357.

27) C. C. Doumanidis and D. E. Hardt: J. Dyna. Sys. Measur. Contr., 111 (1989), 40.

28) G. M. Oreper, T. W. Eagar and J. Szekely: Weld. J., 62 (1983), No. 11,307 s.

29) K. Poorhaydari, B. M. Patchett and D. G. Ivey: Weld. J., 84 (2005), No. $10,149 \mathrm{~s}$.

30) D. Rosenthal: Weld. J., 20 (1941), No. 5, 220s

31) D. Rosenthal: Trans. ASME, 68 (1946), 849.

32) O. R. Myhr and O. Grong: Acta Metall. Mater., 38 (1990), No. 3, 449.

33) J. N. DuPont and R. E. Mizia: Report-INL/EXT-10-18459, Idaho National Laboratory, ID, (2010)

34) J. N. Dupont, S. W. Banovic and A. R. Marder: Weld. J., 82 (2003), No. $6,125 \mathrm{~s}$

35) S. K. Bose and H. J. Grabke: Z. Metallkd., 69 (1978), No. 1, 8

36) S. J. Lee, D. K. Matlock and C. J. V. Tyne: ISIJ Int., 51 (2011), No. $11,1903$.

37) C. Sudha, R. Anand, S. Saroja and M. Vijayalakshmi: Trans. IIM, 63 (2010), No. 4, 739.

38) P. K. Ghosh, P. C. Gupta, N. B. Potluri and Y. Gupta: ISIJ Int., 44, (2004), No. 7, 1201.

39) R. Dehmolaei, M. Shamanian and A. Kermanpur: Mater. Char., 59 (2008), No. 10, 1447.

40) M. Pozuelo, J. E. Wittig, J. A. Jime'nez and G. Frommeyer: Metall. Mater. Trans. A, 40A ( 2009), 1826.

41) A. Baltusnikas and R. Levinskas: Mater. Sci. (MEDŽIAGOTYRA), 12 (2006), No. 3, 192. 